\title{
Interferon treatment of multiple pulmonary malignancies associated with papilloma virus
}

\author{
S Aaron $M D^{1}$, E Wong $M D^{1}$, D Tyrrell $M D^{1}, M$ Duggan $M D^{2}$, E Vallieres $M D^{3}$, \\ $\mathrm{L}$ Jewell $M D^{1}$, B Romanowski $M D^{1}$, Patient John Doe*
}

\begin{abstract}
S Aaron, E Wong, D Tyrrell, et al. Interferon treatment of multiple pulmonary malignancies associated with papilloma virus. Can Respir J 2004;11(6):443-446.

Over a period of four years, beginning in spring 1988, a previously healthy man developed a primary squamous cell carcinoma of the tonsil, treated with radiotherapy, followed by 10 distinct, primary bronchial squamous cell carcinomas. Four of the cancers were surgically resected, all of which were positive by hybridization for human papilloma virus (type 16). Following the institution of alpha interferon, three smaller lesions disappeared and a larger one shrank in size, facilitating surgical resection. Over the following seven years no new ones have appeared. The finding of papilloma virus in malignancies should prompt consideration of antiviral therapy.
\end{abstract}

Key Words: Interferon; Lung; Papilloma virus; Squamous cell carcinoma; Tonsil
$\mathrm{H}$

uman papilloma virus (HPV) is associated with malignancy of the oropharynx and respiratory tract $(1-8)$. This was first described in the context of juvenile polyposis of the trachea (4). More recently, the virus has been described in the context of adult respiratory tract cancers (5-8). We describe an adult patient who developed dermatomyositis (treated with steroids), a tonsillar carcinoma (treated with radiotherapy) and then multiple primary squamous cell carcinomas of the bronchial tree. These malignancies have all been found to hybridize for HPV, and the patient has responded dramatically to high-dose interferon therapy.

\section{CASE HISTORY}

In spring 1988, a previously well 37-year-old man was diagnosed as having dermatomyositis on the basis of increasing proximal weakness, typical rash, elevated creatine kinase (CK), abnormal electromyogram and muscle biopsy. His only previous medical history had been recent severe grief reaction and depression, followed by periodontal surgery complicated by gingivitis. He never
Le traitement à l'interféron de tumeurs pulmonaires malignes multiples associées au virus à papillome

En l'espace de quatre ans, à compter du printemps 1988, un homme auparavant en santé a développé un carcinome spinocellulaire primaire de l'amygdale, traité par radiothérapie, suivi de dix carcinomes spinocellulaires bronchiques primaires. Quatre des cancers ont été réséqués par voie chirurgicale, et tous étaient positifs par hybridation au virus à papillome humain (type 16). Après l'adoption d'un traitement à l'interféron alpha, trois petites lésions ont disparu, et le foyer d'une quatrième, plus grosse, a diminué, facilitant la résection chirurgicale. Au cours des sept années suivantes, aucune nouvelle tumeur n'a fait son apparition. La découverte de papillome humain en présence d'une tumeur maligne devrait inciter à envisager rapidement une thérapie aux antiviraux.

*It was the patient's own perseverance and research that first indicated the possibility that a papilloma virus infection might underlie his recurring malignancies. He, in turn, urged his physicians to pursue first this diagnosis and then the possibility of immune therapy, without which he would have surely died. This included both interferon and intravenous immunoglobulin to prevent further immunosuppression. Since 1992, he has been the driving force behind this investigation and paper in the hope that it will ultimately save lives by alerting physicians treating similar patients suffering from malignancies with suspected viral origins. It was also the patient's idea to check his papilloma titres. The patient's recovery and contribution to this effort have been remarkable.

${ }^{1}$ University of Alberta, Edmonton, Alberta; ${ }^{2}$ University of Calgary, Calgary, Alberta; ${ }^{3}$ Swedish Cancer Institute, Seattle, Washington, USA

Correspondence: Dr Stephen Aaron, 562 Heritage Medical Research Centre, Edmonton, Alberta T6G 2S2.

Telephone 780-407-6762, fax 780-407-6055, e-mail stephen.aaron@ualberta.ca 
The lesion in the left lung was followed until May 1991, when a thoracotomy and left upper lobe wedge resection was performed, revealing a squamous cell carcinoma $1.8 \mathrm{~cm}$ in diameter. Postoperatively, he lost $8 \mathrm{~kg}$ and had difficulty regaining or maintaining weight despite high caloric intake. For the rest of that year his myositis remained active and he was continued on steroids with the addition of low-dose methotrexate for three weeks. In September, radiographs revealed a new lesion in the right lung. A right upper lobe wedge resection was performed in October 1991, showing the presence of a new squamous cell carcinoma of $2.4 \mathrm{~cm}$ as well as evidence of a distinct adjacent focus of carcinoma in situ.

In February 1992, the patient noted a productive cough with blood streaking. Three areas of carcinoma in situ were found on endoscopic biopsy of the left bronchial tree. Lung imaging fluorescence endoscopy analysis of his bronchial tree did not reveal additional lesions. Following treatment of intercurrent zoster with acyclovir, the patient was treated with photodynamic therapy and retinoic acid with success. In May, he was begun on intermittent intravenous immunoglobulin for his persistent myositis.

In July, bronchoscopy showed no new lesions. In September 1992, a new mass near the left hilum and three other, smaller, left-sided lesions became apparent on x-ray and computed tomography. Bronchial washings confirmed the presence of malignant cells.

Specimens of the lung tumours resected in 1991 and 1992, as well specimens from the tonsillar malignancy were submitted for analysis with probes for HPV in July 1992. Both lung tumours were positive by in situ hybridization and polymerase chain reaction amplification for HPV 16. In addition, the tumour that was resected in 1992 was found positive for HPV 35. The tonsillar malignancy was similarly positive for HPV 16.

As a result of the analysis, he was placed on alpha interferon, $(3,000,000$ units, four times a week) in September 1992. All but the larger lesion seen near the left hilum resolved over the following eight months. This remaining lesion $(3.5 \mathrm{~cm})$ was resected by left upper lobectomy in July 1993. Sections were analyzed and were also found to be positive for HPV 16. Cis retinoic acid was added to his therapy for 12 weeks (September 20 to December 20).

The patient was continued on the interferon until May 1993 and has been monitored by regular bronchoscopies, chest $\mathrm{x}$-rays and analyses for residual HPV.

From 1992 to July 2003, no new malignancies have appeared. The most recent bronchial wash was negative for HPV (May 10, 2001). Genetic testing performed on skin biopsies taken in October 1992 failed to reveal any independent predisposition to malignancy. In early 1993, the patient was diagnosed with hyperthyroidism (Grave's disease) which was treated surgically to avoid further radiation. In that year he was also noted to have hypogonadism with reduced testosterone. This was found to be secondary to reduced pituitary activity.

The patient's strength has stabilized, but has not returned to premorbid levels. His CK remains elevated in the range of $500 \mathrm{IU}$ to $700 \mathrm{IU}$.

A specimen of serum collected from the patient in March 2003 was tested for antibodies to HPV 16- and HPV 18-like particles by quantitative enzyme-linked immunosorbent assay (ELISA). Testing was performed at GlaxoSmithKline Biologicals, Belgium, using a modification of the methods reported by Evans et al (9). The quantity of antibody was expressed in ELISA units per $\mathrm{mL}(\mathrm{EL} \mathrm{U} / \mathrm{mL}$ ) based on an internal reference standard established for each ELISA; the positive cut-point was $8 \mathrm{EL} \mathrm{U} / \mathrm{mL}$ or greater for HPV 16 and $7 \mathrm{EL} \mathrm{U} / \mathrm{mL}$ for HPV 18.

The test for antibody to HPV 16 was positive at $30 \mathrm{EL} \mathrm{U} / \mathrm{mL}$. The test for antibody to HPV 18 ELISA was negative at less than $7 \mathrm{EL} \mathrm{U} / \mathrm{mL}$. To assess the meaning of detecting $30 \mathrm{EL} \mathrm{U} / \mathrm{mL}$ of serum antibody to HPV 16 in the patient, a panel of serum specimens from women with and without HPV 16 cervical infection was tested. Virginal women without HPV 16 cervical infection had a geometric mean titre of $4 \mathrm{EL} \mathrm{U} / \mathrm{mL}$. Nonvirginal women with no HPV 16 DNA detected in cervical cells by polymerase chain reaction had a GMT of $5 \mathrm{EL} \mathrm{U} / \mathrm{mL}$. Nonvirginal women with abnormal cervical cytology and HPV 16 DNA detected in cervical cells by polymerase chain reaction had a geometric mean titre of $20 \mathrm{EL} \mathrm{U} / \mathrm{mL}$ (F Dessy, personal communication).

\section{DISCUSSION}

This patient had developed 11 primary malignancies of the oral cavity and bronchial tree in the three years before the institution of antiviral therapy in 1992. Seven of those primaries appeared in rapid succession in the nine months before therapy with alpha interferon. Four of the tumours were surgically resected and all of these were found to have evidence of HPV 16 infection. These include the original tonsillar cancer and the three surgically resected lung cancers. In addition, at least one of the tumours and several of the bronchial washings were positive for other HPV types. At least four of the lesions first became apparent after the time that immunosuppressive therapy with steroids for his dermatomyositis was replaced by intravenous immunoglobulin. However, from the time that interferon was begun, the patient has had no new malignancies and has had spontaneous resolution of several suspicious radiological lesions.

The histological examination of the multiple tonsillar and pulmonary lesions removed from this patient all showed moderately differentiated squamous carcinomas of papillary configuration. Areas of in situ carcinoma were identified adjacent to the main invasive lesions, which grew with a broad 'pushing', both in the tonsil and in the lung. This finding suggests that the lesions originated in a multicentric fashion in different portions of the aerodigestive tract. No benign papillomatous lesions were found anywhere in the airway, nor did the tonsil exhibit benign squamous papilloma or features suggestive of a condylomatous lesion. Accordingly, there was no pathological evidence to support the notion that this multicentric HPV-associated lesion originated from malignant transformation of a pre-existing benign laryngeal papillomatosis or related condition (Figures 1, 2 and 3).

Almost certainly this patient's malignant diathesis, including his original tonsillar tumour, was due to infection with papilloma virus. This relationship seems likely given the disappearance of lesions and the absence of new ones after therapy with interferon commenced. The development of multiple 


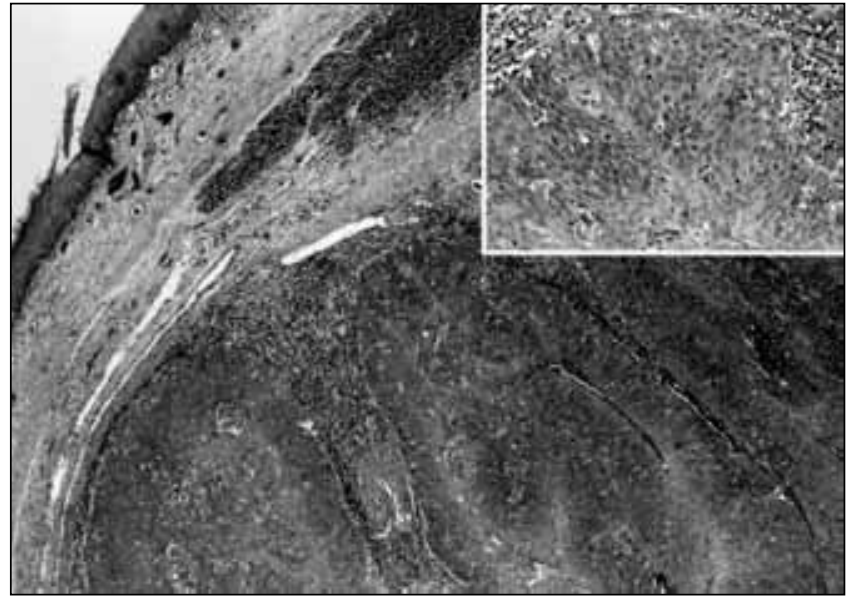

Figure 1) Sections of the tonsil removed in 1989 show extensive invasion of tonsillar substance by a poorly differentiated squamous cell carcinoma (hematoxylin and eosin stain, original magnification $\times 55$ ). The inset (hematoxylin and eosin stain, original magnification $\times 140$ ) shows numerous mitotic figures and cellular anaplasia

pulmonary malignancies over a short period of time may well have been associated with radiotherapy of a HPV-induced tumour. There are multiple reports of malignant conversion of benign papillomatous lesions following radiotherapy $(4,5,7,10,11)$. There had been previous reports of the response of HPV-induced lesions to interferon in both the cervix and respiratory tract $(12-14)$.

We sought to avoid broadly immunosuppressive therapy in view of the acceleration of HPV associated with malignancies in the cervix and in patients treated with these agents. $(15,16)$. This intravenous immunoglobulin was used for our patient's myositis with some success. However, several new lesions appeared even after the time that this change was made (September 1992).

The frequency of HPV carriage in lower airway malignancy has been reported to be anywhere from 5\% to $30 \%$ in various series. This finding seems to be mainly confined to squamous cell carcinoma. The method by which the presence of HPV is documented or suspected varied enormously.

The antibody results in our patient are similar to those observed in women with established cervical HPV 16 infection. They are consistent with a systemic antibody response elicited by HPV 16 infection of the oropharynx and lower respiratory epithelium (9).

This finding supports the existence of an HPV 16 infection of these tissues, diagnosed by detection of virus genome using polymerase chain reaction.

In younger patients, particularly those who have minimal to no history of tobacco exposure, awareness of the possible viral pathogenecity of these lesions is warranted $(10,17-21)$. As indicated above, radiotherapy for the initial lesion likely played a role in the multiple squamous cell carcinomas that subsequently developed.

The response of this patient to the institution of interferon would recommend consideration of these measures for patients in similar clinical circumstances (22).

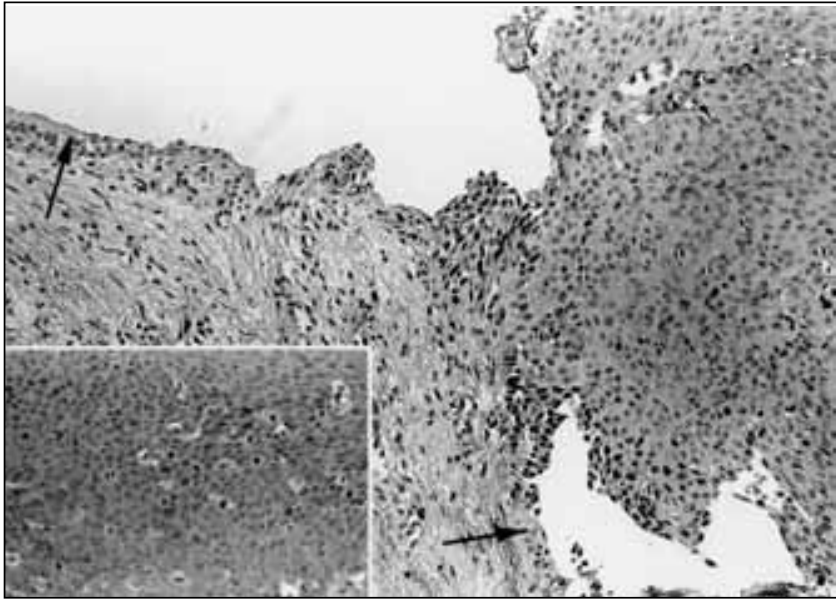

Figure 2) A 1992 bronchial mucosal biopsy shows superficially invasive squamous cell carcinoma arising in the bronchial mucosa. Surviving respiratory mucosa is identified by arrows (hematoxylin and eosin stain, original magnification $\times 220$ ). The inset shows a poorly differentiated squamous cell carcinoma with numerous mitoses and cellular anaplasia closely resembling the tonsillar lesion of 1989 (hematoxylin and eosin stain, original magnification $\times 225$ ). This suggests multicentric malignancies

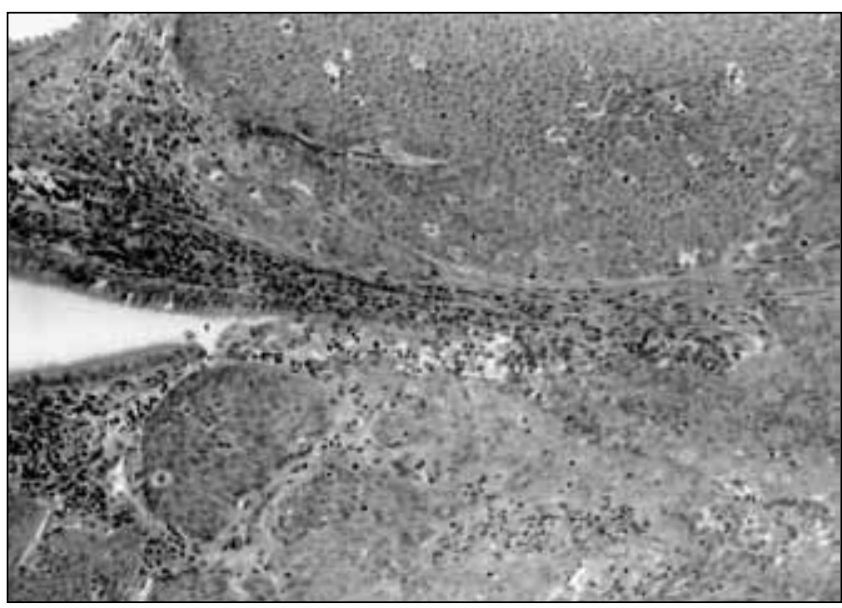

Figure 3) Sections of the lobectomy (October 1991) show invasive squamous cell in relation to respiratory mucosa. (hematoxylin and eosin stain, original magnification $\times 210$ )

\section{REFERENCES}

1. Galloway TC, Soper GR, Elsen J. Carcinoma of the larynx after irradiation for papilloma. Arch Otolarayngol 1960;72:289-94.

2. Rabbett WF. Juvenile laryngeal papillomatosis. The relation of irradiation to malignant degeneration in this disease. Ann Otol Rhinol Laryngol 1965;74:1149-63.

3. Majoros M, Devine K, Parkhill EM. Malignant transformation of benign laryngeal papillomas in children after radiation therapy. Surg Clin North Am 1963;43:1049-61.

4. Gaylis B, Hayden RE. Recurrent respiratory papillomatosis: Progression to invasion and malignancy. Am J Otolaryngol 1991;12:104-12.

5. Bryne JC, Tsao M, Fraser RS, Howley PM. Human papillomavirus-11 DNA in a patient with chronic laryngotracheobronchial papillomatosis and metastatic sqamous-cell carcinoma of the lung. N Engl J Med 1987;317:873-8.

6. Syrjanen KJ, Syrjanen SM. Human papillomavirus DNA in endobronchial squamous cell carcinomas. Lancet 1987;1:168-9.

7. Crissman JD, Kessis T, Shah KV, et al. Squamous papillary neoplasia of the adult upper aerodigestive tract. Hum Pathol 1988;19:1387-96. 
8. Yousem SA, Ohori NP, Sommez-Alpan E. Occurrence of human papillomavirus DNA in primary lung neoplasms. Cancer 1992;69:693-7.

9. Evans TG, Bonnez W, Rose RC, et al. A Phase 1 study of a recombinant viruslike particle vaccine against human papillomavirus type 11 in healthy adult volunteers. J Infect Dis 2001;183:1485-93.

10. Chang F, Wang L, Syrjanen S, Syrjanen K. Human papillomavirus infections in the respiratory tract. Am J Otolaryngol 1992;13:210-25.

11. Lindeberg $\mathrm{H}$, Elbrond $\mathrm{O}$. Malignant tumors in patients with a history of multiple laryngeal papillomas: The significance of irradiation. Clinical Otolaryngol 1991;16:149-51.

12. Gall SA, Constantine L, Koukol D. Therapy of persistent human papillomavirus disease with two different interferon species. Am J Obstet Gynecol 1991;164:130-4.

13. Richtsmeier WJ, Koch WM, McGuire WP, Poole ME, Chang EH. Phase I-II study of advanced head and neck squamous cell carcinoma patients treated with recombinant human interferon gamma. Arch Otolaryngol Head Neck Surg 1990;116:1271-7.

14. Leventhal BG, Kashima HK, Weck PW, et al. Randomized surgical adjuvant trial of interferon alpha-n1 in recurrent papillomatosis. Arch Otolaryngol Head Neck Surg 1988;114:1163-9.

15. Vardy DA, Baadsgaard O, Hansen ER, Lisby S, Vejlsgaard GL. The cellular immune response to human papillomavirus infection. Int J Dermatol 1990;29:603-10.

16. Petry KU, Scheffel D, Bode U, et al. Cellular immunodeficiency enhances the progression of human papillomavirus-associated cervical lesions. Int J Cancer 1994;57:836-40.
17. Syrjanen KJ. Bronchial squamous cell carcinomas associated with epithelial changes identical to condylomatous lesions of the uterine cervix. Lung 1980;158:131-42.

18. Syrjanen K, Syrjanen S, Kellokoski J, Karja J, Mantyjarvi R. Human papillomavius (HPB) type 6 and 16 DNA sequences in bronchial squamous cell carcinomas demonstrated by in situ DNA hybridization. Lung 1989;167:33-42.

19. Bejui-Thivolet F, Liagre N, Chignol M, Chardonnet Y, Patricot LM. Detection of human papillomavirus DNA in squamous bronchial metaplasia and squamous cell carcinomas of the lung by in situ hybridization using biotinylated probes in paraffin-embedded specimens. Human pathol 1990;21:111-6.

20. Kinoshita I, Dosaka-Akita H, Shindoh M, et al. Human papillomavirus type $18 \mathrm{DNA}$ and E6-E7 mRNA are detected in squamous cell carcinoma and adenocarcinoma of the lung. Br J Cancer 1995;71:344-9.

21. Kealey M, Vallieres E, Perkins G, Shamji F. Human papillomavirus DNA in squamous cell lung cancer patients under 60 years of age. Canadian Association of General Surgeons. Banff, June 1997.

22. Schouten TJ, Van Den Broek P, Cremers CW, Jongerius CM, Meyer JW, Vooys GP. Interferons and bronchogenic carcinoma in juvenile laryngeal papillomatosis. Arch Otolanryngol 1983;109:289-91

23. Koutsky LA, Ault KA, Wheeler CM, et al, Proof of Principle Study Investigators. A controlled trial of a human papilloma virus type 16 vaccine. N Engl J Med 2002;347:1645-51. 


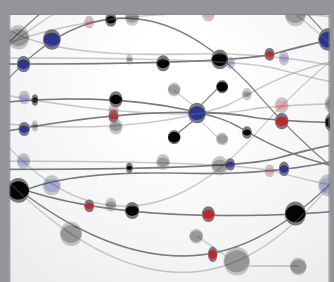

The Scientific World Journal
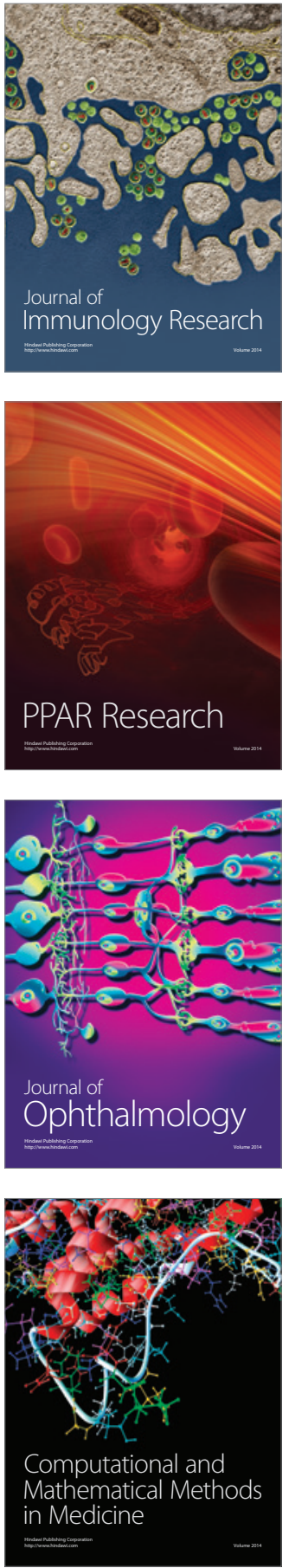

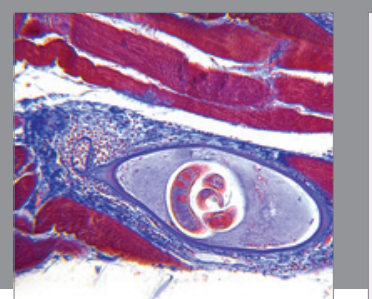

Gastroenterology Research and Practice

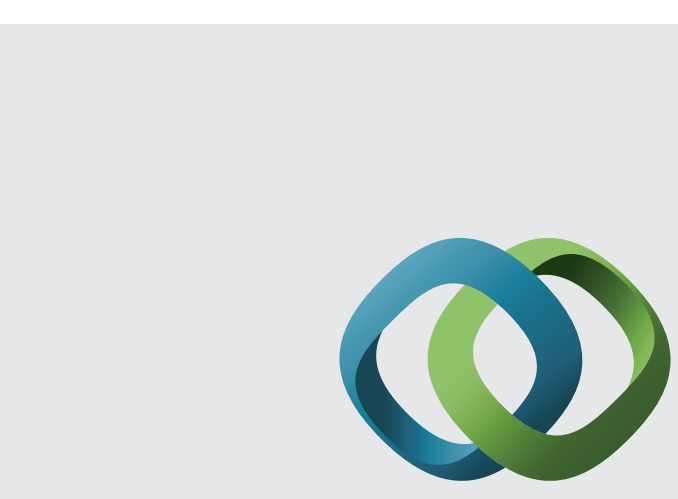

\section{Hindawi}

Submit your manuscripts at

http://www.hindawi.com
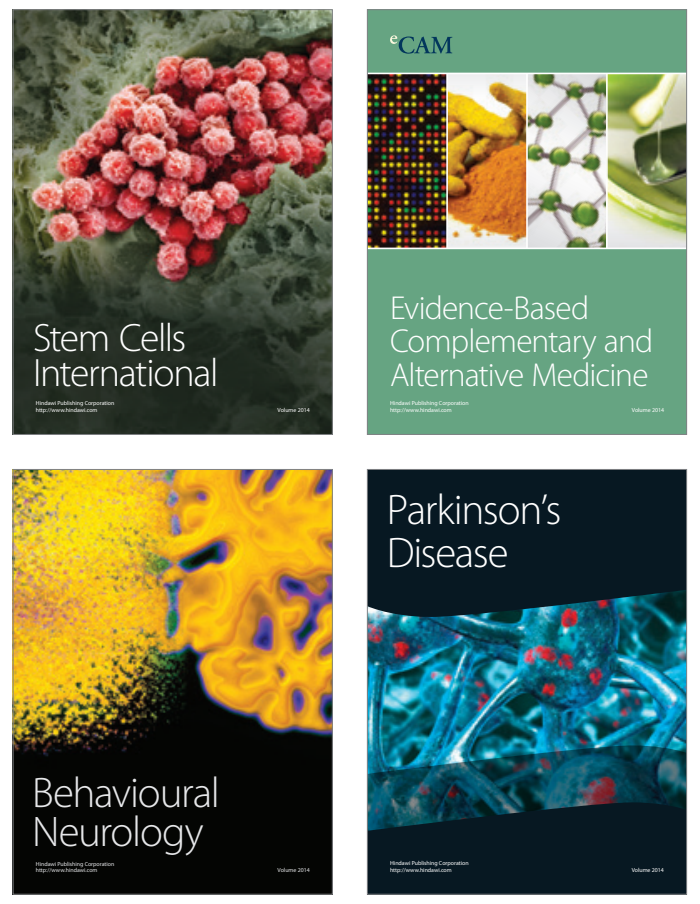
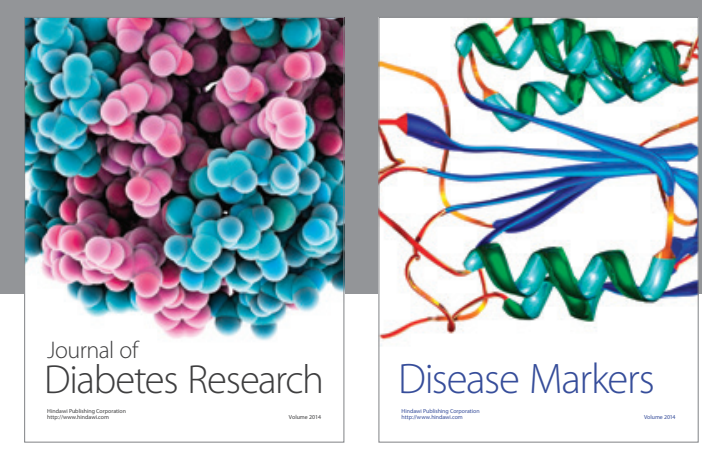

Disease Markers
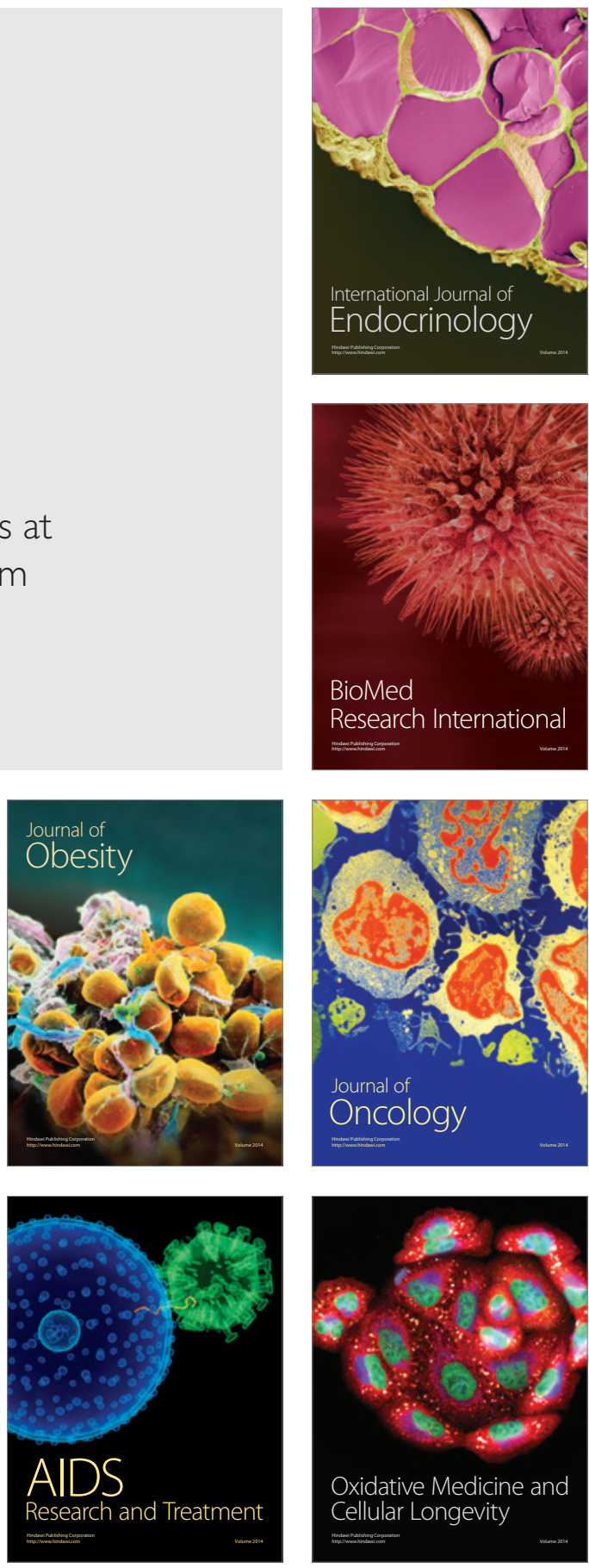